\title{
PENGARUH LINGKUNGAN KERJA TERHADAP KINERJA PERANGKAT NAGARI DALAM PENGELOLAAN KEUANGAN NAGARI DI KABUPATEN TANAH DATAR
}

\author{
Nur Putri Jayanti \\ Jurusan Administrasi Publik, Fakultas Ilmu Sosial, Universitas Negeri Padang \\ nurputrijayanti1128@gmail.com

\section{Syamsir} \\ Jurusan Administrasi Publik, Fakultas Ilmu Sosial, Universitas Negeri Padang \\ syamsir@fis.unp.ac.id
}

\begin{abstract}
Law No. 6/2014 stated that the Village Government should be able to perform the task of managing village finances with a large budget and to provide accountability for the expenditure. The problems that occurred in Tanah Datar were that the nagari treasurers were less transparent about the nagari's financial management. The purpose of this study was to analyze the influence of work environment on the performance of nagari apparatus in managing nagari finance. This study used quantitative method. The population in this study consisted of 525 respondents and 227 of them were chosen as sample determined with Slovin formula and proportional random sampling technique. The data were analyzed with linear regression. The result of this study indicated that simultaneously and partially the work environment had significant effects on the performance of the nagari apparatus in the management of nagari finance in Tanah Datar District.
\end{abstract}

Keywords: Work environment, Nagari apparatus, financial management

How to Cite: Nur Putri Jayanti. 2018. Pengaruh Lingkungan Kerja Terhadap Kinerja Perangkat Nagari dalam Pengelolaan Keuangan Nagari di Kabupaten Tanah Datar. 2(1): pp.35-46, DOI: https://doi.org/10.24036/jess/vol2-iss1

\section{Pendahuluan}

Istilah "desa" terdapat pada Pasal 1 Undang-Undang Nomor 6 Tahun 2014 yang menyebutkan bahwa desa dalam penyebutannya dapat disesuaikan dengan istilah lain sesuai dengan asal usul daerahnya, dan untuk di Provinsi Sumatera Barat desa dikenal dengan sebutan "nagari". M. Ali (2016) memaparkan bahwa dengan disahkannya Undang-Undang Nomor 6 Tahun 2014 Tentang Desa yang merupakan salah satu konsep Pemerintah Indonesia dalam melaksanakan pemerintahan dan pembangunan dengan konsep dari bawah, sehingga perlu untuk melakukan pemberdayaan menuju masyarakat yang sejahtera. Maka dari itu, salah satu yang perlu dikelola dalam tataran desa adalah pengelolaan keuangan desa yang memiliki alokasi anggaran yang besar. Keuangan desa menurut Permendagri Nomor 113 Tahun 2014 Pasal 1 adalah semua hak dan kewajiban desa yang 
dinilai dengan uang serta segala sesuatu yang berhubungan dengan pelaksanaan hak dan kewajiban desa tersebut. Keuangan desa dikelola berdasarkan praktikpraktik pemerintahan yang baik, meliputi perencanaan, pelaksanaan, penatausahaan, pelaporan dan pertanggungjawaban (Deputi Bidang Pengawasan Penyelenggaraan Keuangan Daerah, 2015). Pengelolaan ini nantinya akan dikelola pada tenggang waktu satu tahun anggaran mulai dari tanggal 1 Januari s/d 31 Desember (Perbup. Tanah Datar Nomor 11 Tahun 2014, Pasal 3).

Salah satu fakta yang ditemukan di lapangan adalah bahwa beberapa nagari di Kabupaten Tanah Datar masih memiliki fasilitas komputer yang belum memadai dan belum ada transparansi (keterbukaan) dalam pengelolaan keuangan nagari. Nagari Pitalah Kecamatan Batipuh salah satu contohnya, sekretaris nagari menyatakan bahwa dalam mengelola keuangan nagari bendahara nagari jarang melaporkan kondisi keuangan nagari kepada perangkat nagari lainnya, sehingga mengindikasikan bahwa nagari ini belum mampu menerapkan asas transparan dan asas akuntabel dalam mengelola keuangan nagari sesuai Permendagri Nomor 113 Tahun 2014. Permasalahan lain juga terjadi di Nagari Bungo Tanjung Kecamatan Batipuh. Pada nagari ini terjadi perubahan sistem dalam pengelolaan keuangan nagari dan adanya kendala dalam bentuk kurangnya bimbingan teknis dan pelatihan dari pihak yang berkompeten, sehingga dalam penginputan data keuangan perangkat nagari harus mempelajarinya kembali.

Selanjutnya Kaur Ekonomi Nagari Simabur Kecamatan Pariangan juga menjelaskan bahwa pada nagari ini keterlibatan perangkat nagari dalam perencanaan dan penganggaran APBNagari masih minim (tidak melibatkan kaur), sehingga transparansi dalam pengelolaan keuangan nagari tidak ada. Di sisi lain, keuangan nagari di Nagari Rao-Rao Kecamatan Sungai Tarab pada tahun anggaran 2016 tidak habis digunakan sehingga menjadi bagian dari SiLPA di Rekening Kas Umum Nagari sebesar Rp. 700.000.000,- dengan sanksi yang terdapat pada Peraturan Pemerintah Nomor 8 Tahun 2016 berupa penundaan penyaluran dana tahun anggaran berjalan sebesar sisa dana nagari.

Untuk mengelola keuangan nagari dengan baik maka hal yang harus dilakukan adalah mempunyai fasilitas yang terjamin, seperti komputer atau laptop, adanya keterbukaan informasi masalah pendapatan dan pembelanjaan nagari, adanya prosedur yang jelas serta didukung dengan sarana dan prasarana dalam mengelola keuangan, serta masyarakat mengerti pada anggaran pendapatan dan belanja nagari. Irsyad Fikri (2016) mengemukakan bahwa dalam mengelola keuangan nagari dibutuhkan pengelola yang handal dan mengerti dengan tata cara pengelolaan terdiri dari peraturan, sistem pengelolaan, maupun pertanggungjawaban keuangan. Untuk mendukung kinerja dalam pengelolaan keuangan nagari maka dalam bekerja diperlukan lingkungan kerja yang sehat, aman, dan nyaman. Lingkungan kerja adalah seluruh alat dan bahan yang ada disekitar lingkungan seseorang bekerja meliputi metode kerja dan pengaturan kerja, baik perorangan maupun kelompok, dan pada dasarnya lingkungan kerja meliputi lingkungan kerja fisik dan lingkungan kerja nonfisik (Sedarmayanti, 2009).

Permasalahan yang terjadi pada beberapa nagari di Kabupaten Tanah Datar mengenai lingkungan kerja, antara lain: pada Nagari Tanjung Barulak Kecamatan Batipuh memiliki permasalahan mengenai tata cara komunikasi dan hubungan 
kerja antar perangkat nagari dalam bekerja kurang baik. Nagari Pitalah Kecamatan Batipuh memiliki permasalahan mengenai koordinasi antar perangkat nagari tidak dapat terjalin dengan baik. Dengan kata lain, permasalahan ini mengarah pada lingkungan kerja nonfisik yang kurang baik. Pada Nagari Situmbuk Kecamatan Salimpauang memiliki permasalahan mengenai fasilitas penginputan data-data keuangan nagari hanya memiliki satu komputer. Nagari Supayang Kecamatan Salimpauang memiliki permasalahan mengenai adanya perbaikan kantor Walinagari yang menjadikan kondisi dalam kantor ini kurang nyaman bagi perangkat nagari dalam beraktivitas.

Selanjutnya, Nagari Tapi Selo Kecamatan Lintau Buo Utara memiliki permasalahan mengenai jarak staf nagari dalam memberikan pelayanan dengan masyarakat sangat dekat. Pada Nagari Saruaso Kecamatan Tanjung Emas memiliki permasalahan mengenai ruangan untuk bekerja sempit, bahkan untuk bertatap muka menggunakan ruangan Walinagari. Hal yang sama juga terjadi pada Nagari Padang Ganting yang memiliki permasalahan mengenai ruangan untuk bekerja kurang memadai dan fasilitas untuk penginputan data-data keuangan di Nagari Atar masih minim.

Berdasarkan permasalahan di atas maka peneliti telah melakukan penelitian dengan mengemukakan rumusan masalah sebagai berikut:

1. Apakah terdapat pengaruh lingkungan kerja fisik terhadap kinerja perangkat nagari dalam pengelolaan keuangan nagari di Kabupaten Tanah Datar?

2. Apakah terdapat pengaruh lingkungan kerja nonfisik terhadap kinerja perangkat nagari dalam pengelolaan keuangan nagari di Kabupaten Tanah Datar?

3. Apakah terdapat pengaruh lingkungan kerja fisik dan nonfisik secara bersama-sama terhadap kinerja perangkat nagari dalam pengelolaan keuangan nagari di Kabupaten Tanah Datar?

Mengingat keterbatasan peneliti dalam melakukan penelitian, maka peneliti membatasi perangkat nagari yang terlibat terdiri atas sekretaris nagari, bendahara nagari, dan 5 kaur dan staf yang menjadi Pelaksana Teknis Pengelolaan Keuangan Nagari (PTPKN).

\section{Kajian Pustaka}

\section{Kinerja}

Wirawan (2009) menyatakan bahwa kinerja adalah keluaran yang dihasilkan oleh fungsi atau indikator tertentu. Selanjutnya Frifin (dalam Sule, 2005) menjelaskan bahwa kinerja terbaik ditetapkan melalui tiga faktor, seperti motivasi (keinginan untuk melakukan pekerjaan), kapabilitas (kemampuan dari sumber daya manusia untuk melakukan pekerjaan), dan lingkungan pekerjaan (situasi untuk melakukan pekerjaan).

Secara umum, indikator dalam mengukur kinerja birokrasi publik (Agus Dwiyanto, 2006:50) meliputi produktivitas, kualitas layanan, responsivitas, responsibilitas dan akuntabilitas. Namun ada tiga unsur dasar yang dapat menentukan kinerja yang akan di nilai oleh pihak manajemen terhadap kinerja 
individu (Kusuma, 2017) diantaranya yaitu karakter, perilaku, dan hasil personalitas individual.

\section{Pengelolaan Keuangan Desa/Nagari}

Istilah "desa" terdapat pada Pasal 1 Undang-Undang Nomor 6 Tahun 2014 yang menyebutkan bahwa penyebutan desa dapat disesuaikan dengan istilah lain sesuai asal usul daerahnya, dan untuk di Provinsi Sumatera Barat desa dikenal dengan sebutan "nagari". Perangkat desa/nagari dalam penelitian ini mengacu kepada penjelasan dalam Permendagri Nomor 113 Tahun 2014 Pasal 4 yang menjelaskan bahwa perangkat nagari terdiri atas sekretaris desa/nagari, bendahara desa/nagari, dan kepala seksi terdiri dari lima urusan yaitu urusan umum, perekonomian, pembangunan, pemerintahan, kesejahteraan rakyat. Secara umum tugas perangkat desa/nagari adalah membantu Kepala Desa/Walinagari dalam melaksanakan wewenangnya. Selain itu, tugas perangkat desa/nagari adalah untuk melaksanakan pengelolaan keuangan pemerintah desa/nagari.

Pemegang kekuasaan pengelolaan keuangan nagari adalah Walinagari dan dapat dilimpahkan kepada sekretaris nagari yang dibantu oleh kepala urusan umum (Perbup Nomor 11 Tahun 2014 Pasal 4). Perangkat nagari yang ditunjuk oleh Walinagari untuk melaksanakan pengelolaan keuangan pemerintah nagari disebut dengan Pelaksana Teknis Pengelola Keuangan Nagari (PTPKN).

Keuangan desa/nagari adalah semua hak dan kewajiban desa/nagari yang dapat dinilai dengan uang serta segala sesuatu yang berhubungan dengan pelaksanaan hak dan kewajiban tersebut. Siklus pengelolaan keuangan desa/nagari terdiri dari perencanaan, pelaksanaan, penatausahaan, pelaporan, dan pertanggungjawaban, dengan tenggang satu tahun anggaran dimulai tanggal 1 Januari s/d 31 Desember (Deputi Bidang Pengawasan Penyelenggaraan Keuangan Daerah, 2015). Seluruh pendapatan desa/nagari, yang masuk melalui Rekening Kas Desa, pencairan dananya harus disertai tanda tangan Kepala Desa dan Bendahara Desa serta ditetapkan dalam Anggaran Pendapatan dan Belanja Desa/Nagari (PP Nomor 43 Tahun 2014 Pasal 91-92).

Siklus dalam membuat Anggaran Pendapatan dan Belanja Desa/Nagari dijelaskan dalam Permendagri Nomor 113 Tahun 2014 Pasal 8-19, sebagai berikut:

1) Pendapatan Desa/Nagari

Pendapatan desa/nagari adalah semua penerimaan uang melalui rekening desa, dalam artian hak desa dalam satu tahun anggaran yang tidak perlu dibayar kembali oleh desa seperti pendapatan asli desa dan jenis swadaya.

2) Belanja Desa/Nagari

Belanja Desa/Nagari adalah semua pengeluaran dari rekening desa, dalam artian kewajiban desa dalam satu tahun anggaran yang tidak akan diperoleh pembayarannya kembali oleh desa, seperti belanja pegawai, belanja barang dan jasa, serta belanja modal.

3) Pembiayaan Desa/Nagari

Pembiayaan Desa/Nagari adalah semua penerimaan atau pengeluaran yang akan dibayar atau diterima kembali, baik pada tahun anggaran bersangkutan maupun pada tahun anggaran berikutnya. 
Edy Supriadi (2015) menjelaskan bahwa prinsip pengelolaan keuangan desa/nagari dalam memenuhi tata kelola pemerintahan yaitu aspiratif, partisipatif, transparan, dan akuntabilitas. Perbup Kabupaten Tanah Datar Nomor 11 Tahun 2014 menjelaskan pula bahwa keuangan nagari dikelola secara tertib, taat pada peraturan perundang-undangan, efektif, efisien, ekonomis, transparan, dan bertanggungjawab dengan melihat asas keadilan, kepatutan, dan manfaat untuk masyarakat. Keuangan desa/nagari dikelola melalui praktik pemerintahan yang baik yang dijadikan indikator sebagai pengukur kinerja perangkat nagari dalam pengelolaan keuangan nagari yang dilihat berdasarkan asas-asas dalam Permendagri Nomor 113 Tahun 2014, sebagai berikut:

1) Transparan, merupakan prinsip keterbukaan yang memungkinkan masyarakat untuk mengetahui dan mendapatkan akses informasi seluas-luasnya tentang keuangan nagari.

2) Akuntabel, merupakan perwujudan kewajiaban seseorang untuk mempertanggungjawabakan pengelolaan dan pengendalian sumber daya dan pelaksanaan kebijakan yang dipercayakan kepadanya dalam rangka pencapaiaan tujuan yang telah ditetapkan.

3) Partisipatif, dapat dilakukan dengan cara mengikutsertakan masyarakat dan kelembagaan yang ada di nagari.

4) Secara Tertib dan Disiplin Anggaran; secara tertib diartikan bahwa keuangan nagari dikelola secara tepat waktu dan tempat guna serta adanya bukti-bukti administrasi yang dapat dipertanggungjawabkan. Sedangkan, secara disiplin anggaran diartikan bahwa pengelolaan keuangan nagari harus berpedoman pada peraturan perundang-undangan.

\section{Lingkungan Kerja}

Edy Sutrisno (2010) menjelaskan bahwa lingkungan kerja adalah keseluruhan sarana dan prasarana kerja di sekitar pegawai yang sedang melakukan pekerjaan sehingga mampu mempengaruhi pelaksanaan pekerjaan, seperti: tempat bekerja, fasilitas (dana, alat bantu pekerjaan), kebersihan, pencahayaan, ketenangan, termasuk juga hubungan kerja antara orang-orang yang ada di dalamnya. Menurut Nitisemito (2002) lingkungan kerja adalah segala sesuatu yang ada di sekitar para pekerja dan mampu mempengaruhinya dalam menjalankan tugas yang diberikan.

Diana (2013) menjelaskan bahwa secara umum lingkungan kerja dipengaruhi beberapa faktor, seperti fasilitas kerja, gaji dan tunjangan serta hubungan kerja. Secara khusus Sedarmayanti (2011) memaparkan bahwa faktor yang mempengaruhi lingkungan kerja fisik adalah: penerangan/cahaya, temperatur, kelembaban, sirkulasi udara, kebisingan, getaran mekanis, bau-bauan, tata warna, dekorasi, musik, dan keamanan di tempat kerja. Sementara menurut Moekijat (2002), faktor-faktor yang dapat dilihat dari lingkungan kerja fisik adalah penerangan, warna, musik, udara, dan suara. Selanjutnya secara khusus Sihombing dalam Elda Cintia (2016) memaparkan bahwa faktor yang mempengaruhi lingkungan kerja nonfisik adalah hubungan kerja atasan dan bawahan serta hubungan antar sesama pegawai. 
Indikator yang menjadi rujukan sebagai pengukur lingkungan kerja dalam penelitian ini adalah indikator seperti yang dikemukakan oleh Sedarmayanti (2009) yang menyatakan bahwa lingkungan kerja adalah seluruh alat dan bahan yang ada di sekitar lingkungan seseorang bekerja meliputi metode kerja dan pengaturan kerja, baik perorangan maupun kelompok. Secara garis besar, Sedarmayanti (2009) memaparkan bahwa lingkungan kerja terbagi atas 2 jenis, sebagai berikut:

1) Lingkungan Kerja Fisik, yaitu semua keadaan yang terdapat di sekitar tempat kerja yang akan mempengaruhi pegawai baik secara langsung maupun tidak langsung, meliputi perlengkapan kerja dan kondisi kantor.

2) Lingkungan Kerja Nonfisik, yaitu semua keadaan yang terjadi dan berkaitan dengan hubungan kerja, meliputi hubungan dengan atasan maupun hubungan sesama rekan kerja, sehingga lingkungan kerja nonfisik merupakan lingkungan kerja yang tidak bisa diabaikan.

\section{Pengaruh Lingkungan Kerja Terhadap Kinerja}

Pengelolaan merupakan bentuk dari kinerja. Siagian (2002) menjelaskan bahwa kinerja karyawan dipengaruhi oleh beberapa faktor, seperti gaji, lingkungan kerja, budaya organisasi, kepemimpinan dan motivasi kerja, disiplin kerja, kepuasan kerja, komunikasi dan faktor-faktor lainnya. Nitisemito dalam Anak Agung (2012) menyebutkan bahwa faktor lain yang mempengaruhi kinerja dalam melaksanakan tugas adalah lingkungan kerja. Berdasarkan hal ini untuk meningkatkan kinerja pegawai/karyawan salah satunya adalah dengan memperhatikan faktor lingkungan kerja.

Penelitian terdahulu yang dilakukan oleh Iwan (2004) tentang Analisis Pengaruh Lingkungan Kerja Terhadap Kinerja Aparat Pemerintah menunjukkan bahwa lingkungan kerja berpengaruh signifikan terhadap kinerja. Diana (2013) dalam penelitiannya mengenai Pengaruh Lingkungan Kerja Terhadap Kinerja Kerja Pegawai BAPPEDA menemukan bahwa terdapat pengaruh secara signifikan antara lingkungan kerja terhadap kinerja pegawai pada BAPPEDA Kabupaten X. Hal yang sama juga ditemukan dalam penelitian Fariz (2013), Eldaa (2016), Nadiya (2014), dan Anak Agung (2012) bahwa lingkungan kerja berpengaruh positif terhadap kinerja karyawan. Namun, penelitian Dwi Agung (2013) dengan judul Pengaruh Kedisiplinan, Lingkungan Kerja, dan Budaya Kerja Terhadap Kinerja Tenaga Pengajar menemukan bahwa secara parsial lingkungan kerja tidak berpengaruh signifikan terhadap kinerja tenaga pengajar.

\section{Hipotesis Penelitian}

Hipotesis adalah jawaban sementara terhadap masalah penelitian dengan kata lain disebut sebagai kesimpulan bersifat sementara. Sehingga untuk menerima maupun menolak hipotesis tergantung pada hasil penelitian dalam penelitian ini dengan kesimpulan sebagai berikut:

1) Terdapat pengaruh yang signifikan antara lingkungan kerja fisik terhadap kinerja perangkat nagari dalam pengelolaan keuangan nagari di Kabupaten Tanah Datar. 
2) Terdapat pengaruh signifikan antara lingkungan kerja nonfisik terhadap kinerja perangkat nagari dalam pengelolaan keuangan nagari di Kabupaten Tanah Datar.

3) Terdapat pengaruh signifikan antara lingkungan kerja fisik dan lingkungan kerja nonfisik secara bersama-sama terhadap kinerja perangkat nagari dalam pengelolaan keuangan nagari di Kabupaten Tanah Datar.

\section{Metode Penelitian}

Metode penelitian ini adalah penelitian kuantitatif dengan jenis penelitian asosiatif menggunakan hubungan kausal (sebab akibat). Variabel bebas dalam penelitian ini adalah lingkungan kerja $(\mathrm{X})$ yang mencakup dua sub variabel yaitu lingkungan kerja fisik $\left(\mathrm{X}_{1}\right)$ dan lingkungan kerja nonfisik $\left(\mathrm{X}_{2}\right)$. Variabel terikat dalam penelitian ini adalah pengelolaan keuangan nagari (Y). Lokasi penelitian ini adalah beberapa kenagarian di Kabupaten Tanah Datar dengan populasi seluruh perangkat nagari yang berjumlah 75 nagari terdiri atas seorang sekretaris nagari, seorang bendahara nagari, serta lima kepala urusan dan staf dengan jumlah unit populasi sebanyak 525 orang. Namun karena keterbatasan peneliti, maka sampel ditarik menggunakan Teknik Sampel Acak Proporsional (Proportional Random Sampling) dan menggunakan Rumus Slovin sehingga didapatkan sampel dengan jumlah responden sebanyak 227 orang.

Instrumen dalam penelitian ini menggunakan angket atau kuesioner, untuk variabel $X$ terdapat 8 pernyataan meliputi 4 pernyataan untuk $X_{1}$ dan 4 pernyataan untuk $\mathrm{X}_{2}$, serta untuk variabel $\mathrm{Y}$ terdapat 15 pernyataan meliputi aspek transparan, akuntabel, partisipatif, tertib dan disiplin anggaran. Masing-masing pernyataan diukur menggunakan skala likert dengan jawaban dari sangat setuju hingga sangat tidak setuju dan memiliki nilai yang berbeda mulai pada angka 4 sampai 1 . Selanjutnya data diolah dengan menggunakan teknik analisis regresi linier berganda.

\section{Hasil Penelitian dan Pembahasan}

Sebelum penyebaran kuesioner di lapangan, peneliti melakukan uji validitas dan uji reliabilitas pada setiap pernyataan, dan dilakukan pada responden di luar sampel. Berdasarkan uji validitas yang telah dilakukan maka diketahui hasilnya adalah setiap pernyataan dalam angket dinyatakan valid pada nilai Corrected Item-Total Correlation lebih besar dari 0,361. Kemudian setiap penyataan dalam angket juga dinyatakan reliabel pada nilai Croanbach's Alpha If Item Deleted yang lebih besar dari 0,60 .

Berdasarkan analisis data terlihat bahwa TCR pada variabel lingkungan kerja dan variabel pengelolaan keuangan nagari berada pada kategori "tinggi". Jika dilihat pada kategori mean responden maka variabel lingkungan kerja berada sedikit di atas rata-rata sebesar 52\%, sehingga dapat disimpulkan bahwa kondisi lingkungan kerja perangkat nagari dalam pengelolaan keuangan nagari tergolong "baik" di Kabupaten Tanah Datar. Sedangkan TCR variabel pengelolaan keuangan nagari berada di bawah rata-rata sebesar $64 \%$, sehingga dapat 
disimpulkan bahwa kinerja perangkat nagari dalam pengelolaan keuangan nagari masih tergolong "rendah" di Kabupaten Tanah Datar.

Hasil uji asumsi klasik dilakukan menggunakan program SPSS versi 21 dengan melibatkan variabel independen yaitu lingkungan kerja fisik $\left(\mathrm{X}_{1}\right)$ dan lingkungan kerja nonfisik $\left(\mathrm{X}_{2}\right)$ serta variabel dependen yaitu pengelolaan keuangan nagari (Y). Hasil uji asumsi klasik ini mengisyaratkan bahwa data ini dapat diolah dengan regresi linear berganda. Analisis ini digunakan untuk mengetahui besar pengaruh antara variabel bebas terhadap variabel terikat. Pengujian pada penelitian ini dilakukan dengan tingkat kepercayaan 95\% atau tingkat kesalahan $5 \%(a=0,05)$.

Setelah dilakukan pengujian asumsi klasik, maka pengujian selanjutnya adalah menggunakan persamaan regresi berganda yaitu:

$$
\mathrm{Y}=35,243+0,690 \mathrm{X}_{1}+0,288 \mathrm{X}_{2}
$$

Penjelasan: konstanta sebesar 35,243 menunjukan bahwa sebelum adanya variabel bebas $(\mathrm{X})$ dalam kantor wali nagari, maka besarnya kinerja perangkat nagari dalam pengelolaan keuangan nagari sebesar 35,243. Apabila variabel lingkungan kerja fisik $\left(\mathrm{X}_{1}\right)$ mengalami peningkatan satu satuan, maka kinerja perangkat nagari dalam pengelolaan keuangan nagari (Y) akan naik sebesar 0,690 satuan dengan asumsi variabel yang lainnya dianggap konstan. Begitu juga dengan variabel lingkungan kerja nonfisik $\left(\mathrm{X}_{2}\right)$, apabila terjadi peningkatan satu satuan, maka kinerja perangkat nagari dalam pengelolaan keuangan nagari (Y) akan naik sebesar 0,288 satuan dengan asumsi variabel yang lainnya dianggap konstan. Dengan kata lain, apabila lingkungan kerja fisik dan lingkungan kerja nonfisik meningkat maka akan diikuti oleh peningkatan kinerja perangkat nagari dalam pengelolaan keuangan nagari di Kabupaten Tanah Datar.

Secara lebih jelas hasil pengolahan data penelitian ini dapat dilihat pada gambar 1 dan Tabel 1 berikut ini:

\section{Gambar 1: Pengaruh dan Kontribusi Variabel X Terhadap Y}

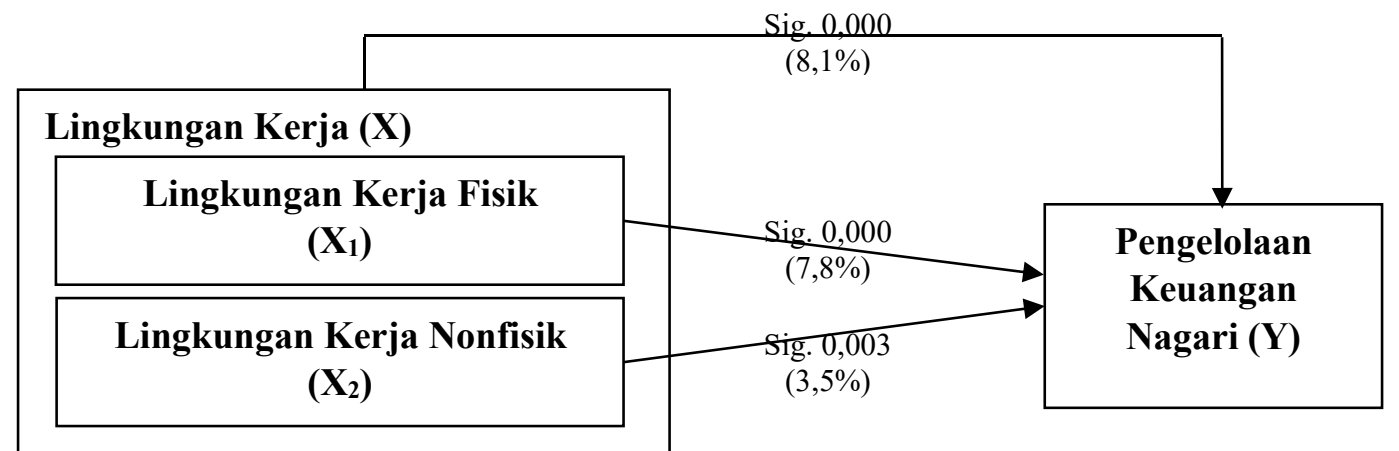

Sumber: Hasil Pengolahan Data Penelitian 2018 
Tabel 1: Hasil Pengujian Hipotesis

\begin{tabular}{|l|l|l|}
\hline $\mathrm{X}_{1}$ Terhadap Y & Sig. 0,000<0,05 & $\begin{array}{l}\mathrm{H}_{\mathrm{a}} \text { diterima } \\
\mathrm{H}_{0} \text { ditolak }\end{array}$ \\
\hline $\mathrm{X}_{2}$ Terhadap Y & Sig. 0,003 $<0,05$ & $\begin{array}{l}\mathrm{H}_{\mathrm{a}} \text { diterima } \\
\mathrm{H}_{0} \text { ditolak }\end{array}$ \\
\hline X Terhadap Y & Sig. 0,000<0,05 & $\begin{array}{l}\mathrm{H}_{\mathrm{a}} \text { diterima } \\
\mathrm{H}_{0} \text { ditolak }\end{array}$ \\
\hline
\end{tabular}

Sumber: Hasil Pengolahan Data Penelitian 2018

Berdasarkan Gambar 1 dan Tabel 1 di atas dapat dipahami bahwa secara sendiri-sendiri lingkungan kerja fisik berpengaruh positif terhadap kinerja perangkat nagari dalam pengelolaan keuangan nagari. Hal ini terlihat dari nilai Adjusted $R$ Square sebesar 0,078 yang artinya kontribusi pengaruh lingkungan kerja fisik terhadap pengelolaan keuangan nagari sebesar $7,8 \%$ dan memiliki kekuatan sebesar 28,6\% dengan signifikansi sebesar 0,000. Di sisi lain, secara sendiri-sendiri lingkungan kerja nonfisik juga berpengaruh positif terhadap kinerja perangkat nagari dalam pengelolaan keuangan nagari. Hal ini terlihat dari nilai Adjusted $R$ Square sebesar 0,035 yang artinya kontribusi pengaruh lingkungan kerja nonfisik terhadap pengelolaan keuangan nagari sebesar 3,5\% dan memiliki kekuatan sebesar 19,8\% dengan signifikansi sebesar 0,003 didapatkan penjelasan bahwa terdapat pengaruh lingkungan kerja nonfisik. Berdasarkan kekuatan pengaruh yang dihasilkan maka didapatkan kesimpulan bahwa variabel bebas yang banyak berpengaruh terhadap variabel terikat adalah variabel lingkungan kerja fisik.

Selanjutnya, secara bersama-sama lingkungan kerja fisik dan nonfisik berpengaruh positif terhadap kinerja perangkat nagari dalam pengelolaan keuangan nagari terlihat dari nilai Adjusted $R$ Square sebesar 0,081\% yang artinya kontribusi pengaruh lingkungan kerja fisik dan nonfisik terhadap pengelolaan keuangan nagari sebesar $8,1 \%$ dan dapat dipercaya $100 \%$ untuk memprediksi kinerja perangkat nagari dalam pengelolaan keuangan nagari sedangkan sisanya 91,9\% dipengaruhi oleh faktor lain yang tidak diteliti dalam penelitian ini. Seperti teori yang dikemukakan oleh S.P. Siagian (2002) bahwa faktor lain tersebut adalah gaji, budaya organisasi, kepemimpinan, motivasi kerja, disiplin kerja, kepuasan kerja, dan komunikasi. Rivai (2005:16) juga memaparkan bahwa faktor lain itu adalah kemampuan dan keinginan. Kedua variabel bebas memiliki kekuatan sebesar 29,8\% serta dilihat dari nilai signifikansi sebesar 0,000 didapatkan penjelasan bahwa terdapat pengaruh lingkungan kerja fisik dan 
lingkungan kerja nonfisik terhadap kinerja perangkat nagari dalam pengelolaan keuangan nagari.

\section{Penutup}

Berdasarkan hasil penelitian dan pembahasan seperti telah diuraikan sebelumnya, maka peneliti menyimpulkan sebagai berikut:

1) Pengaruh lingkungan kerja fisik terhadap kinerja perangkat nagari dalam pengelolaan keuangan nagari secara parsial (sendiri-sendiri) ada sebesar 7,8\% dan pengaruh lingkungan kerja nonfisik terhadap kinerja perangkat nagari dalam pengelolaan keuangan nagari secara parsial (sendiri-sendiri) ada pula sebesar 3,5\%. Pengaruh yang lebih dominan dari variabel bebas terhadap variabel terikat pada penelitian ini ada pada variabel lingkungan kerja fisik.

2) Pengaruh lingkungan kerja fisik dan lingkungan kerja nonfisik terhadap kinerja perangkat nagari dalam pengelolaan keuangan nagari secara simultan (bersama-sama) sebesar $8,1 \%$ dan dapat dipercaya 100\% untuk memprediksi kinerja perangkat nagari dalam pengelolaan keuangan nagari sedangkan sisanya 91,9\% dipengaruhi oleh faktor lain yang tidak diteliti dalam penelitian ini, yang dapat berupa gaji, budaya organisasi, kepemimpinan, motivasi kerja, disiplin kerja, kepuasan kerja, komunikasi, kemampuan dan keinginan.

Terkait dengan kesimpulan ini maka peneliti memberikan saran dalam penelitian ini, sebagai berikut:

1) Hasil penelitian dan pembahasan menunjukan bahwa lingkungan kerja fisik mempunyai pengaruh yang dominan terhadap kinerja perangkat nagari dalam pengelolaan keuangan nagari. Saran yang peneliti tawarkan adalah perlu adanya peningkatan dengan cara memperhatikan penataan ruangan dengan kondisi kantor yang lebih baik, sirkulasi udara yang membuat perangkat nagari nyaman, fasilitas umum yang perlu ditambah seperti kursi dan meja untuk tamu, dan perlengkapan kerja seperti komputer dan laptop yang tersedia bagi masing-masing perangkat nagari sehingga akan meningkatkan kinerja perangkat nagari dalam mengelola keuangan nagari.

2) Hasil penelitian dan pembahasan juga menunjukan bahwa lingkungan kerja nonfisik mempunyai pengaruh yang lebih rendah dibandingkan lingkungan kerja fisik, maka peneliti menyarankan agar Wali Nagari dan perangkat nagari dapat meningkatkan solidaritas dalam bekerja terutama dalam mengelola keuangan nagari, dengan cara memperhatikan hubungan baik antara Walinagari dengan perangkat nagari maupun hubungan antar perangkat nagari dalam bekerja, agar kesalahpahaman dalam menjalankan tugas dapat dikurangi, sehingga kinerja perangkat nagari dalam mengelola keuangan nagari akan terus meningkat.

3) Selanjutnya, penelitian ini masih memiliki kelemahan dalam hal tertentu untuk itu peneliti mengharapkan kepada peneliti selanjutnya untuk dapat menyempurnakan penelitian ini dengan cara menggunakan beberapa faktor lain yang tidak diteliti dalam penelitian ini. 


\section{DAFTAR KEPUSTAKAAN}

Agus Dwiyanto. (2006). Mewujudkan Good Governance Melalui Pelayanan Publik. Yogyakarta: UGM Press.

Anak Agung Ngurah Bagus Dhermawan, dkk. (2012). "Pengaruh Motivasi, Lingkungan Kerja, Kompetensi, Dan Kompensasi Terhadap Kepuasan Kerja Dan Kinerja Pegawai Di Lingkungan Kantor Dinas Pekerjaan Umum Provinsi Bali”. Jurnal Manajemen, Strategi Bisnis Dan Kewirausahaan. Vol. 6, No. 2, Agustus 2012, hlm. 173-184. Fakultas Ekonomi, Universitas Udayana.

Deputi Bidang Pengawasan Penyelenggaraan Keuangan Daerah. (2015). "Petunjuk Pelaksanaan Bimbingan \& Konsultasi Pengelolaan Keuangan Desa". Badan Pengawasan Keuangan dan Pembangunan (BPKP).

Diana Khairani Sofyan. (2013). "Pengaruh Lingkungan Kerja Terhadap Kinerja Kerja Pegawai BAPPEDA". Malikussaleh Industrial Engineering Journal (MIEJ) Journal. Vol. 2, No. 1, 2013, hlm. 18-23. ISSN: 2302 934X. Aceh: Jurusan Teknik Industri, Universitas Malikusaleh.

Dwi Agung Nugroho Arianto. (2013). "Pengaruh Kedisiplinan, Lingkungan Kerja dan Budaya Kerja Terhadap Kinerja Tenaga Pengajar". Jurnal Economia, Vol: 9, No. 2, Oktober 2013. Universitas Islam Nahdiatul Ulama Jepara.

Edy Supriadi. (2015). "Pertanggungjawaban Kepala Desa Dalam Pengelolaan Keuangan Desa Berdasarkan Undang-undang Nomor 6 Tahun 2014 Tentang Desa. Kajian Hukum dan Keadilan”. Jurnal IUS. Vol. III, No. 8, Agustus 2015, hlm. 330-346.

Edy Sutrisno. (2010). Manajemen Sumber Daya Manusia. Jakarta: Kencana Prenada Media Group.

Eldaa Cintia, dkk. (2016). "Pengaruh Lingkungan Kerja Fisik dan Nonfisik Terhadap Kinerja Karyawan Pada KPPN Bandung I'. Jurnal Sosioteknologi. Vol. 15, No. 1, April 2016, hlm. 136-154. Fakultas Komunikasi dan Bisnis, Universitas Telkom.

Fariz Ramanda Putra, dkk. (2013). "Pengaruh Lingkungan Kerja Terhadap Kinerja (Studi Pada Karyawan PT. Naraya Telematika Malang”. Skripsi. Malang: Fakultas Ilmu Administrasi, Universitas Brawijaya

Irsyad Fikri. (2016). "Pertanggungjawaban Pengelolaan Keuangan Nagari Oleh Walinagari Barulak Kabupaten Tanah Datar". Skripsi. Padang: Fakultas Hukum, Universitas Andalas

Iwan Trisno, dkk. (2004). "Analisis Pengaruh Kompensasi dan Lingkungan Kerja Terhadap Kinerja Aparat Pemerintah (Studi Kasus Pada Dinas Perindustrian dan Perdagangan Kabupaten Pati)”. Jurnal Ilmiah Telaah Manajemen. Vol. 1, No. 1, Edisi1. Magister Manajemen, STIE Stikubank. 
Kusuma C.K, dkk. (2017). Evaluasi Kinerja Sumber Daya Manusia (SDM). Cetakan ke-1. Yogyakarta: Gosyen Publishing.

M. Ali Mahmudin. (2016). "Manajemen Pemerintahan Desa Dalam Pengelolaan Dana Desa". Laporan Studi Pustaka (KPM 403). Bogor: Fakultas Ekologi Manusia, Institut Pertanian Bogor.

Moekijat. (2002). Tata Laksana Kantor: Manajemen Perkantoran. Bandung: CV. Mandar Maju.

Nadiya Lifa Ningrum, dkk. (2014). "Pengaruh Lingkungan Kerja Terhadap Kinerja Karyawan (Studi Pada Karyawan Auto 2000 Sukun Malang)". Jurnal Administrasi Bisnis. Vol. 11, No. 1, Juni 2014, hlm. 1-9. Fakultas Ilmu Administrasi, Universitas Brawijaya.

Nitisemito, A.S. (2002). Manajemen Personalia. Jakarta: Salemba Empat.

Rivai, V., dkk. (2005). Performance Appraisal: Sistem Yang Tepat Untuk Menilai Kinerja Karyawan Dan Meningkatkan Daya Saing Perusahaan. Jakarta: PT. RajaGrafindo Persada.

Sedarmayanti. (2009). Sumber Daya Manusia dan Produktivitas Kerja. Bandung: CV. Mandar Maju.

(2011). Membangun Dan Mengembangkan Kepemimpinan Serta Meningkatkan Kinerja Untuk Meraih Keberhasilan. Bandung: PT. Refika Aditama.

Siagian, S.P. (2002). Manajemen Sumber Daya Manusia. Jakarta: Bumi Aksara.

Sule, dkk. (2005). Pengantar Manajemen. Jakarta: Prenamedia Group.

Wirawan. (2009). Evaluasi Kinerja Sumber Daya Manusia: Teori, Aplikasi, dan Penelitian. Jakarta: Salemba Empat.

Undang-Undang Nomor 6 Tahun 2014 Tentang Desa.

Peraturan Pemerintah Republik Indonesia Nomor 43 Tahun 2014 Tentang Peraturan Pelaksanaan Undang-Undang Nomor 6 Tahun 2014 Tentang Desa.

Peraturan Pemerintah Republik Indonesia Nomor 8 Tahun 2016 Tentang Perubahan Kedua Atas Peraturan Pemerintah Nomor 60 Tahun 2014 Tentang Dana Desa yang Bersumber dari APBN.

Peraturan Menteri Dalam Negeri Republik Indonesia Nomor 113 Tahun 2014 Tentang Pengelolaan Keuangan Desa.

Peraturan Bupati Tanah Datar Nomor 11 Tahun 2014 Tentang Pedoman Pengelolaan Keuangan Nagari. 